Journal of Southeast Asian

\title{
[Special Issue on SEA Demographics] Response - Community Development
}

Linda Trinh Vo

University of California, Irvine, volt@uci.edu

Follow this and additional works at: https://docs.lib.purdue.edu/jsaaea

Part of the Civic and Community Engagement Commons

\section{Recommended Citation}

Vo, Linda Trinh (2008) "[Special Issue on SEA Demographics] Response - Community Development," Journal of Southeast Asian American Education and Advancement. Vol. 3 : Iss. 1, Article 13. DOI: 10.7771/2153-8999.1109

Available at: https://docs.lib.purdue.edu/jsaaea/vol3/iss1/13

This document has been made available through Purdue e-Pubs, a service of the Purdue University Libraries. Please contact epubs@purdue.edu for additional information.

This is an Open Access journal. This means that it uses a funding model that does not charge readers or their institutions for access. Readers may freely read, download, copy, distribute, print, search, or link to the full texts of articles. This journal is covered under the CC BY-NC-ND license. 


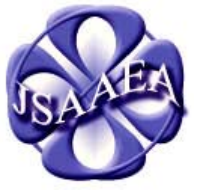

Volume 3
A peer-reviewed scholarly journal published by the National Association for the Education \& Advancement of Cambodian, Laotian, and Vietnamese Americans (NAFEA)

\title{
Special Issue on Southeast Asian American Demographics
}

\section{Response-Community Development}

\author{
Linda Trinh Võ \\ University of California, Irvine
}

In Mark E. Pfeifer's article "Cambodian, Hmong, Lao and Vietnamese-Americans in the 2005 American Community Survey," he highlights significant demographic, educational, and economic changes, some that are unexpected. The survey released by the U.S. Census Bureau indicates that combined, Southeast Asian Americans comprise over 2,260,000 in the United States. This is quite remarkable given that there were only a handful here previous to 1975 when America was engaged in the Vietnam War, which wreaked havoc in Vietnam, Cambodia, and Laos and would contribute to their immigration patterns. They arrived en masse at the end of the war and in various waves in the decades that followed, making it difficult to make generalizations about each ethnic group, since some arrived thirty years ago and others came in the last decade. In this response, I augment the statistical data with contextual and explanatory factors gleaned from my fieldwork and community involvement, as well as address perspectives the data does not reveal.

Average Americans still have a difficult time differentiating between Southeast Asian American groups, or distinguishing them from other Asian Americans. There is an imbalance of the groups, with the Vietnamese population at 1,521,353, Cambodian population at 241,025, Lao population at 209,627, and Hmong population at 188,900. Although research has been conducted on smaller ethnic groups, such as the Iu Mien or Montangards, knowledge about them, even by Asian American Studies scholars is limited. There is only partial data on the ethnic Chinese population, many who came as "boatpeople" refugees from this region, which is a limitation of most datasets. The data show that there are sharp distinctions, such as education and class differences, between and within Southeast Asian American subgroups, so further disaggregation of the data is necessary to avoid broad generalizations (Chan 2006, 2004, 2003, 1994).

\section{Settlement Patterns and Reverse Settlement Patterns}

Southeast Asian Americans were originally dispersed across the fifty states, where they still reside; however, they created cluster areas, especially noticeable with the high numbers in the top five states for each of the groups. The largest population for each of the groups still resides in California. There are differences in regional concentrations, for example, Vietnamese Americans tend to be in concentrated urban areas, whereas the Cambodian and Hmong are in both urban and rural areas. Many have relocated to ethnic enclaves or clusters, where they can find co-ethnics,

Readers are free to copy, display, and distribute this article, as long as the work is attributed to the author(s) and the Journal of Southeast Asian American Education \& Advancement, it is distributed for noncommercial purposes only, and no alteration or transformation is made in the work. More details of this Creative Commons license are available at http://creativecommons.org/licenses/by-nc-nd/3.0/. All other uses must be approved by the author(s) or JSAAEA. 
so having data on the growth at various sites within each of the states would provide more complete migration pattern information. There is also a reverse migration process occurring, in which groups are moving from states like California to more affordable residential areas where they can find suitable employment or where they can operate their businesses with less competition from co-ethnics. What the data does not show is the strong networks these groups have with kin and fictive kin across various sites, and how they pool resources and share knowledge to assist one another. For example, Vietnamese from across the country donated to causes or organizations that helped the Vietnamese American population living in states affected by Hurricane Katrina.

\section{Citizenship and Homeland}

Pfeifer reports that " $26.8 \%$ of Cambodians were not U.S. citizens, compared to $25.2 \%$ of Lao, 23.6\% of Hmong and 18.8\% of Vietnamese” (p.11) and this poses problems for these groups. It should be pointed out that naturalization is not always an available option, since those without an education and English language skills struggle to pass the citizenship test, and they, and their families, live in a precarious situation, especially in the post-911 era when deportation is a reality. Forced to leave their homeland under duress, many Southeast Asian refugees and immigrants still feel a strong affinity to their original homeland. Some became naturalized citizens in order to sponsor relatives as immigrants and also to be able to visit their homeland with the protection that U.S. citizenship affords them, and this accounts for the naturalization rates. Southeast Asian Americans send millions of dollars of remittances to relatives in their homeland, helping to rebuild these countries, which are devastated by war and the turmoil that followed. Those who can afford it travel home to visit relatives, to engage in entrepreneurial ventures, and to do charity work. As the communities become economically more stable, this will enable them to contribute more to their homeland. However, others are wary about helping the political regimes in their homeland or are more focused on extending these resources to address the immediate needs of the local communities in America.

\section{Education and Income}

One of the most significant aspects of the survey, which Pfeifer highlights, is the increasing educational attainment levels of all four groups, showing that Southeast Asian Americans are taking advantage of the educational opportunities provided them. With more socioeconomic stability, educational levels should only increase with co-ethnics assisting new generations to complete high school and attend college. It should be noted that the reason younger generations of Southeast Asian American females are attaining higher levels of education is because of economic necessity, since it allows them to contribute much needed income to their families (Zhou \& Bankston, 1998). It would be helpful to know the generational breakdown to determine if 1.5 and second-generation females are more on par with their male counterparts in terms of academic achievement and income levels. This data does not address the hardships that Southeast Asian American youth face as the first in their families to attend high school and the pressure many of them feel from their parents during college to select pre-med, science, and technology majors. Additionally, examining the experiences of those attending multiethnic and multiracial schools poses new opportunities to interact with diverse groups, but is accompanied by challenges for these youth (Lee, 2005). 
As Pfeifer points out, accompanying this increase in educational attainment is an increase in their income levels. The figure for median household income may be deceiving since more wage-earning adults reside in an average Southeast Asian American household, so this is an inexact measure of socioeconomic mobility. Noticeable differences exist between groups, indicating that Vietnamese and Lao have lower poverty rates than Cambodian and Hmong populations, yet further disaggregated data is needed to show the breakdown within ethnic groups and by region. Although Pfeifer notes the increase in homeownership, it would be useful to know if multigenerational families or if fictive kin are pooling their resources in order to purchase these homes. In terms of occupations, Southeast Asian American males were concentrated in production, transportation, and manufacturing jobs, while females were concentrated in service, sales, and office jobs. Other studies (Pellow \& Park, 2002) have analyzed the preference for Asian immigrant and refugee workers who are perceived to have the dexterity for high-tech assembly work and are perceived to be docile workers, providing unfortunate opportunities for their exploitation. These statistics do not contextualize the extent to which refugee and immigrant women contribute to the survival of their families (Donnelly, 1994; Kibria, 1995). It would be useful to know if younger generation females have made gains in terms of income compared to first-generation women.

\section{Heritage Language Retention and English Language Acquisition}

Pfeifer indicates that $45 \%$ of Cambodian, Lao, and Hmong report that they speak English "less than very well," while Vietnamese reported $50 \%$ and this is consistent with previous findings, showing the continuing challenges for them. Reading and writing in English is difficult for many as well, especially for those who were are not literate in their homeland, such as the Hmong. Community organizations and advocacy groups continually work to ensure that bilingual services and materials are available for their healthcare, educational, political, and consumer needs. These adults who report they speak English "less than very well" are linguistically isolated, relying on their children, who acquire English more readily, to interpret for them. Speaking their ethnic language at home can be interpreted as helping to maintain their ethnic traditions, but more importantly, this enables parents with limited English language abilities to communicate with their children. The numbers are relatively high for families reporting that they speak a language other than English at home; however, this does not reveal some deeper problems, in which children often have minimal fluency in the heritage language, but cannot communicate complex emotions or thoughts with their parents, which creates a generational gap within families. Although the younger generation may be verbally fluent, their reading and writing abilities are limited. Limited English language speakers will help to sustain the ethnic communities, since they rely on it for their services and goods and they also depend on employment in the ethnic communities. For example, this majority foreign-born population ensures that the ethnic language media and entertainment industry is flourishing, including the CD and DVD market and the television, radio, and print media, along with online media formats.

\section{Generation and Community}

As Pfeifer underscores, the native-born population has increased significantly as the foreign-born population has decreased proportionately, with the native-born at 51.3\% for Hmong, $41.7 \%$ for Cambodians, $40.3 \%$ for Lao, and $35.7 \%$ for Vietnamese. This is quite a remarkable change since 
in previous decades this was over $90 \%$ for all the groups. There are few arriving now, so their numbers will not swell like previous periods and their population will increase as a result of domestic birthrates, rather than by new arrivals. In the next twenty years, as the second generation and a third generation comes of age, these communities will face similar problems as the predominately native-born Japanese American population, in regards to sustaining ethnic communities. There is concern that the younger generation will not have the same commitment or need for services provided by the ethnic communities, and this will mean a dissipation of spatial sites. In addition, as this first generation ages, it is necessary for the community to address the needs of the increasing senior citizen population. With the mobility and independence of the younger generations, and with women who are the usual caregivers for the elderly finding employment outside the home, traditional households with multi-generational families residing together is declining. Community leaders are already beginning to address these issues and attempting to find creative ways to sustain their ethnic communities and care for the growing senior citizen population.

\section{Conclusion}

What the survey does not show are the ways in which Southeast Asian Americans are politically active in the communities where they reside. In each of their settlements, there are extensive informal and formal organizations and associations that exist, demonstrating their involvement in ethnic civic engagement and this has been used in a way to sustain co-ethnic collaboration and maintain traditions. However, they have moved beyond the borders of their ethnic communities, with Vietnamese, Cambodian, and Hmong holding elected political positions at the local and state level as well as holding politically appointed positions. It is interesting to note that firstgeneration immigrants or 1.5-generation Southeast Asian Americans hold many of these positions. While many have relied on the ethnic votes and have conducted fundraisers from coethnics in areas outside their district, they have also been astute enough to engage in outreach campaigns with other racial communities as well as mainstream constituents. Within these communities, internal frictions persist that have been transferred from their homeland, and this will probably not abate with the first-generation. A new generation of leaders who do not harbor the same historical animosities is coming of age and their political style differs from their parents. Yet, it has been challenging for them to attain leadership positions, given the expectation of deference to their elders. With their growing ethnic concentrations, a larger U.S.-born population, increased educational attainment, and stable income, they will become more fully incorporated into American society, and one manifestation of this is their political mobilization.

\section{References}

Chan, S., (ed. with contributions by students at the University of California). (2006). The Vietnamese American 1.5 generation: Stories of war, revolution, flight, and new beginnings. Philadelphia, PA: Temple University Press.

Chan, S. (2004). Survivors: Cambodian refugees in the United States. Urbana, IL: University of Illinois Press.

Chan, S., (ed. with Audrey U. Kim). (2003). Not just victims: Conversations with Cambodian community leaders in the United States. Urbana, IL: University of Illinois Press. 
Chan, S., (ed.) (1994). Hmong means free: Life in Laos and America. Philadelphia, PA: Temple University Press.

Donnelly, N. D., (1994). Changing lives of refugee Hmong women. Seattle, WA: University of Washington Press.

Kibria, N., (1995). Family tightrope: The changing lives of Vietnamese Americans. Princeton, NJ: Princeton University Press.

Lee, S. J., (2005). Up against whiteness: Race, school, and immigrant youth. New York: Teachers College Press.

Pellow, D. N., \& Park, L. S. (2002). The silicon valley of dreams: Environmental injustice, immigrant workers, and the high-tech global economy. New York: New York University Press.

Zhou, M. \& Bankston, C.L. III. (1998). Growing up American: How Vietnamese children adapt to life in the United States. New York: Russell Sage Foundation.

\begin{abstract}
About the Author
Dr. Linda Trinh Vo is an Associate Professor and Chair of the Department of Asian American Studies at the University of California, Irvine. She is the author of a book, Mobilizing an Asian American Community about how and why Asian Americans strategically organized for social, cultural, political, and economic purposes. She is the co-editor of three books: Contemporary Asian American Communities: Intersection and Divergences (2002); Asian American Women: The "Frontiers" Reader (2004); and Labor Versus Empire: Race,

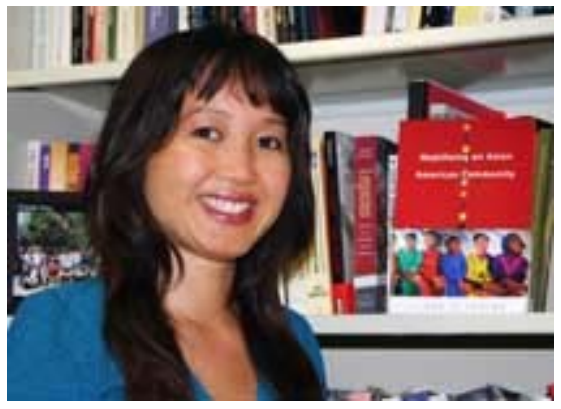
Gender, and Migration (2004).
\end{abstract}




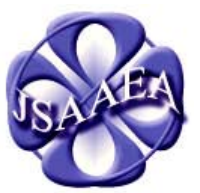

Volume 3

\section{Journal of Southeast Asian American Education \& Advancement} Www.JSAAEA.org

\section{Editor}

Dr. Wayne E. Wright

University of Texas, San Antonio

Associate Editors

Dr. Chhany Sak-Humphry

University of Hawaii

Dr. KimOanh Nguyen-Lam

California State University, Long Beach

Book Review Editor

Dr. Leslie Turpin

School for International Training

Creative Works Editor

Phouang Hamilton

Washington Office of Superintendent of Public Instruction

\section{Special Advisor}

Anne Frank

University of California, Irvine, Southeast Asian Archives

\section{Editorial Assistant \\ Mariana Kuhl}

University of Texas, San Antonio
A peer-reviewed

scholarly journal published by the

National Association

for the Education \&

Advancement of

Cambodian, Laotian,

and Vietnamese

Americans (NAFEA)

Comments and questions for the editorial staff may be directed to jsaaea@lists.sis.utsa.edu

\section{Editorial Review Board}

\author{
Dr. Carl L. Bankston III \\ Tulane University \\ Dr. Phala Chea \\ Lowell Public Schools \\ Dr. Changming Duan \\ University of Missouri, Kansas City \\ Dr. Nancy H. Hornberger \\ University of Pennsylvania \\ Dr. Peter Nien-Chu Kiang \\ University of Massachusetts, Boston \\ Dr. Stacey Lee \\ University of Wisconsin, Madison
}

\author{
Dr. Pollie Bith-Melander \\ Asian and Pacific Islander Wellness Center \\ Dr. George Chigas \\ University of Massachusetts, Lowell \\ Dr. Sophal Ear \\ U.S. Naval Postgraduate School \\ Dr. Samlong Inthaly \\ Minneapolis Public Schools \\ Dr. Kevin K. Kumashiro \\ University of Illinois, Chicago \\ Dr. David Chanpannha Ley \\ Montgomery County Public Schools
}


Dr. Sue Needham

California State University, Dominguez Hills

Dr. Max Niedzwiecki

Rights Working Group

Dr. Clara Park

California State University, Northridge

Dr. Loan T. Phan

University of New Hampshire

Dr. Karen Quintiliani

California State University, Long Beach

Dr. Fay Shin

California State University, Long Beach

Dr. Yer J. Thao

Portland State University

Dr. Khatharya Um

University of California, Berkeley

Dr. Terrence G. Wiley

Arizona State University

\section{Dr. Bic Ngo}

University of Wisconsin-Madison

Dr. Leakhena Nou

California State University, Long Beach

Dr. Mark Pfeifer

Texas A\&M University, Corpus Christi

Dr. Bounlieng Phommasouvanh

Minnesota Department of Education

Dr. Kalyani Rai

University of Wisconsin, Milwaukee

Dr. Nancy J. Smith-Hefner

Boston University

Dr. Myluong Tran

San Diego State University

Dr. Linda Trinh Vo

University of California, Irvine

Dr. Zha Blong Xiong

University of Minnesota

Dr. Kou Yang

California State University, Stanislaus

\section{Doctoral Student Editorial Review Board}

Keo Chea

University of Pennsylvania

Loan Dao

University of California, Berkeley

Ha Lam

Arizona State University

Vanna Som

Harvard University

Giang Pham

University of Minnesota

Tinou Tran

University of Houston, Texas

Phitsamay Sychitkokhong Uy

Harvard University
Vichet Chhuon

University of California, Santa Barbara

Annie BichLoan Duong

San Joaquin County Office of Education

Ravy Lao

University of California, Santa Barbara

Rassamichanh Souryasack

University of California, Santa Barbara

Layheng Ting

State University of New York, Albany

Loan Tran

University of California, Santa Barbara

Yang Sao Xiong

University of California, Los Angeles 